\title{
Impact of High-Density Urban Built Environment on Chronic Obstructive Pulmonary Disease: A Case Study of Jing' an District, Shanghai
}

\author{
Lan Wang ${ }^{1}$, Rui Chen ${ }^{2}$, Wenyao Sun ${ }^{1}$, Xiaoming Yang ${ }^{3, *}$ and Xinhu Li ${ }^{1, *}$ \\ 1 College of Architecture and Urban Planning, Tongji University, 1239 Siping Road, Shanghai 200092, China; \\ wanglan@tongji.edu.cn (L.W.); $1630043 @$ tongji.edu.cn (W.S.) \\ 2 Institute of Engineering and Industry, Tongji University, 1239 Siping Road, Shanghai 200092, China; \\ chenrui_tongji@163.com \\ 3 Jing'an District Center for Disease Control and Prevention, Shanghai 200072, China \\ * Correspondence: yangjiewater@163.com (X.Y.); xhli@tongji.edu.cn (X.L.); Tel.: +86-159-6080-6936 (X.L.)
}

Received: 9 December 2019; Accepted: 26 December 2019; Published: 30 December 2019

check for updates

\begin{abstract}
Respiratory health is a focus of interdisciplinary studies involving urban planning and public health. Studies have noted that urban built environments have impacts on respiratory health by influencing air quality and human behavior such as physical activity. The aim of this paper was to explore the impact of urban built environments on respiratory health, taking chronic obstructive pulmonary disease (COPD) as one of the typical respiratory diseases for study. A cross-sectional study was conducted including all cases $(\mathrm{N}=1511)$ of death from COPD in the high-density Jing'an district of Shanghai from 2001 to 2010. Proxy variables were selected to measure modifiable features of urban built environments within this typical high-density district in Shanghai. A geographically weighted regression (GWR) model was used to explore the effects of the built environment on the mortality of COPD and the geographical variation in the effects. This study found that land use mix, building width-height ratio, frontal area density, and arterial road density were significantly correlated to the mortality of COPD in high-density urban area. By identifying built environment elements adjustable by urban planning and public policy, this study proposes corresponding environmental intervention for respiratory health.
\end{abstract}

Keywords: built environment; COPD; respiratory health; geographically weighted regression

\section{Introduction}

Chronic obstructive pulmonary disease (COPD) is a major chronic respiratory disease, which ranked the third among all causes of death in 2016 according the World Health Organization (WHO) [1]. The prevalence of COPD among population ages $20-39$ and over 40 were $8.6 \%$ and $13.7 \%$, respectively, in China [2]. COPD, with airway and/or alveolar abnormality, is characterized by persistent respiratory symptoms and airflow limitation [3]. COPD is also characterized by a slow and sustained development. There are many factors that threaten the death of patients throughout the whole course of the disease.

Epidemiological studies have demonstrated that the development of COPD is mainly affected by personal characteristics (e.g., genetics, age, gender, and smoking status), exposure to air pollution, socioeconomic status, and physical activity [3-7]. Sudden cardiac death, heart failure, respiratory failure, chronic hypoxia and carbon dioxide retention, increased pulmonary artery pressure, and chronic impairment of lung function are risk factors of death for COPD patients [8-12], and the damage of COPD to human organs increases with aging [12-15]. Death from COPD presents its significant association with air pollutants $[16,17]$. The human exposure to air pollution is associated with increased 
mortality [18]. A high prevalence of COPD was reported in urban areas, especially in high-density areas [19-21]. The possible effects of urban built environments on COPD, therefore, may function through two ways: air quality and physical activity. First, urban built environments could influence the concentration and distribution of atmospheric particle matters by specific spatial factors. It includes: (a) land use (mixed land use [22], land utilization type [23]), (b) road traffic (vehicle emissions [24-26], dwelling distance [27], airflow at road intersection [28,29], isolated green belt along road [30]), (c) green space and open space (single building with complex outdoor space [31-33], green coverage rate and green space types [34], plant leaves with dust effect [35], landscape types and distribution of the surface composition [36]), (d) urban space morphology (block scale [37], valley street space form [22,29,37-39], urban ventilation form $[40,41])$. Second, physical activity can be regarded as an important mediator of the built environment affecting respiratory health. Daily physical activity can decrease the risk of developing COPD [42-48], as well as improve the life quality of COPD patients [49,50]. Available public service facilities, connected road networks, and walkable streets may promote physical activity of residents [51-53]. These urban built environmental exposures thus have impacts on the morbidity and modality of COPD.

Most studies addressing the association between the environment and COPD have mainly focused on the variation of socio-economic environments [54] and natural environments such as altitude [55], temperature [56], and humidity [57]. Little has been reported yet on how urban-built environment exposure can influence individuals' respiratory health. Understanding how modifiable features of urban built environments are associated with the morbidity and modality of respiratory diseases is important as the prevalence of COPD, asthma, and lung cancer are growing concerns to the public health.

The purpose of this study was to investigate the association between modifiable features of urban built environments and respiratory health using COPD as a case. We selected Jing'an District, one of the high-density districts in both population and buildings in Shanghai, as the study area. The geographically weighted regression (GWR) model was developed to identify risk factors of urban built environments on COPD and its geographical variation.

\section{Materials and Methods}

\subsection{Study Area}

Jing'an District, located in the central city of Shanghai, has a total population of 246,788 in 2010 (registered residence and people staying more than six months) and was 7.62 square kilometers before 2015. The population density is 32,387 capita per square kilometer in 2010 and 449 high-rise buildings over 11 floors in 2011 [58]. The jurisdiction of Residential Committee (Juweihui), usually called a neighborhood, was selected as spatial analytic unit. A total of 72 neighborhoods existed in Jing'an District before it was merged with another district in 2015. There were two outliers excluded from the analysis for their unavailable data (Figure 1). 

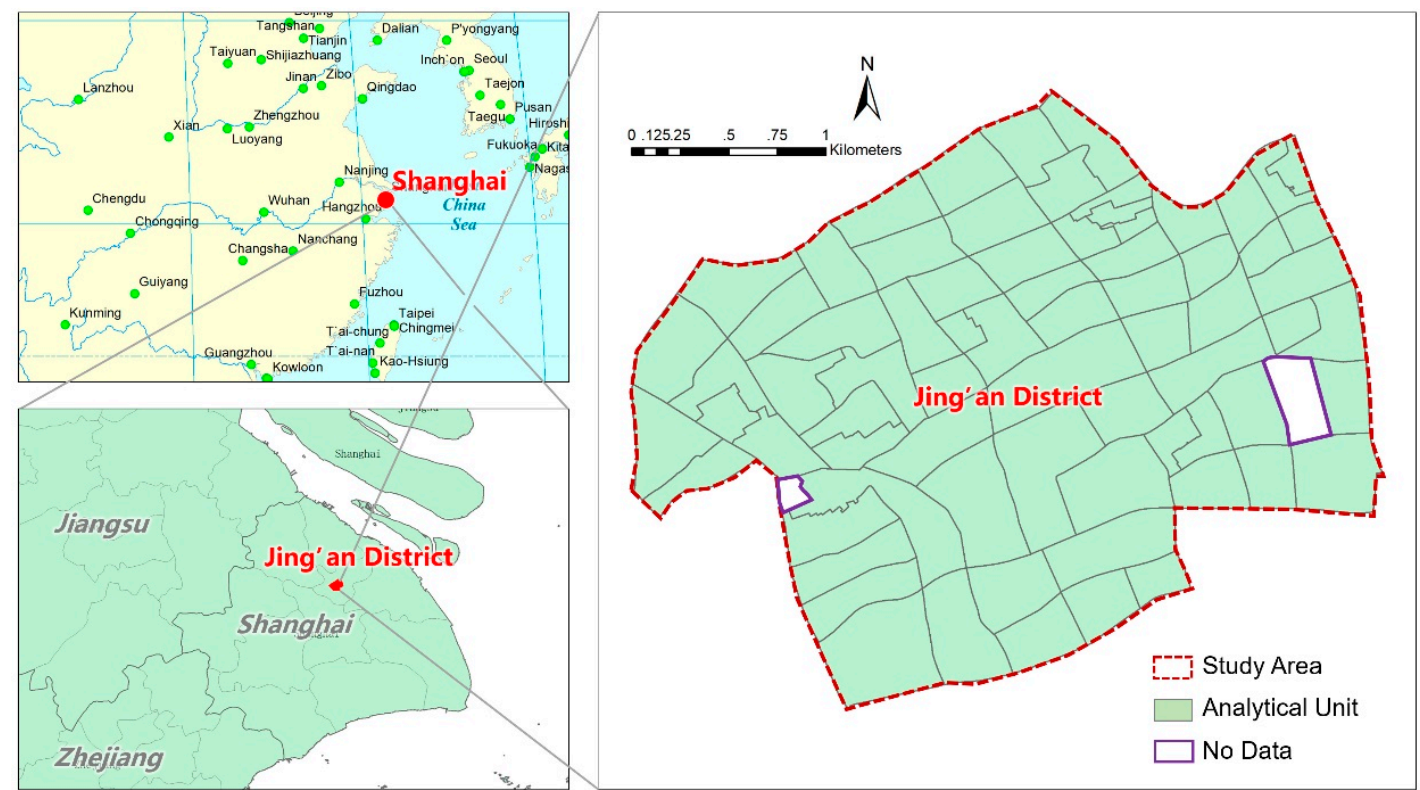

Figure 1. Location and space schematic diagram of the research scope.

\subsection{Data}

The COPD data were obtained from the vital registration database of the Center for Disease Control and Prevention (CDC) of Jing'an District. The database was coded according to the International Classification of Diseases, 10th Revision (ICD 10). Cases registered under J44 in the ICD 10 were regarded as COPD death cases. The information of all deaths from COPD in Jing'an District from 1 January 2001 to 31 December 2010 were extracted from the database, including age, gender, and residential address. 968 male cases and 543 female cases were included in this study. COPD death cases were matched to administrative units (Juweihui, neighborhood) based on residential addresses using Geocoding tools. In Jing'an District, the highest cumulative mortality of COPD was 10,148/100,000, while the lowest was 287/100,000. The average cumulative mortality of COPD was 2260/100,000.

The built environment data in this study were composed of three parts: (1) land use data were obtained from the Urban Planning and Land Resource Bureau of Jing'an District. These data presented the major use for each parcel of land as it was in the year of 2011. It was classified based on the national Code for Classification of Urban Land Use and Planning Standards of Development Land, including residential, administration and public services, commercial and business, etc.; (2) On-site data collection was conducted for each building for its height and style. We thus detailed the residential land according to its housing types, such as linong (2-3 floors), high-rise (11-24 floors), and workers' new villages (4-6 floors). It also enabled the measurements to capture the wind situation within the neighborhood; (3) data for road systems were extracted based on land use data in 2011 through a process of vectorization. We also identified the level of each road including elevated highway, arterial, and branch roads.

Existing studies have demonstrated the impact of a neighborhood's demographic and economic status on respiratory health [59-63] and COPD [64-66]. We included the data about age structure, sex ratio, population education level, and occupation structure of each neighborhood based on the sixth national census in 2010.

\subsection{Measures}

To explore risk factors of urban built environments on COPD and its geographical variation, we employed the GWR model with the neighborhood COPD mortality as the dependent variable, three types of built environment factors as independent variables, and demographic and economic status as covariates (Figure 2). The neighborhood COPD mortality was calculated based on the data from the 
national census and the CDC. Built environment elements were selected according to their impact on air quality and physical activity, including land use, road system, and spatial form. The potential impact of all variables on respiratory health were listed in Table A1 and spatial distributions of built environment elements in Jing'an District were presented in Figure A1.

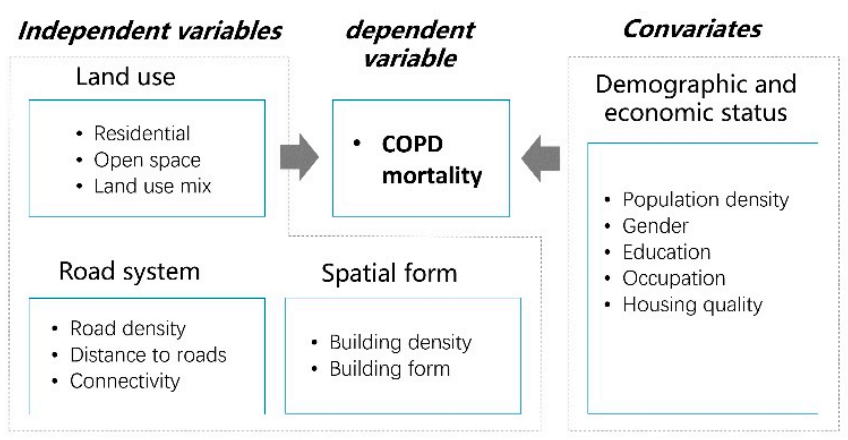

Figure 2. Conceptual framework.

The cumulative mortality rate of COPD was employed because there are few death cases of COPD in neighborhoods per year. The formula is as follows:

$$
\text { mortality }=\mathrm{Nc} / \mathrm{Np} \times 100 \% \text {, }
$$

where Nc is the number of death cases from COPD in a neighborhood, and Np is the total population in a neighborhood. The unit of COPD mortality is the number of death cases per 100,000 population.

For land use, we selected patch density (PD) for residential and open space to measure its distribution. PD is an index to measure the fragmentation of land use. The larger the PD values, the greater it is fragmented. Current studies show that the land fragmentation increases residents' exposure to air pollution. PD of residential and open space for each neighborhood was calculated using the following formula:

$$
\mathrm{PD}=\mathrm{N}_{\mathrm{L}} / \mathrm{A},
$$

where $\mathrm{N}_{\mathrm{L}}$ is the number of land parcels within the neighborhood, and $\mathrm{A}$ is the total area of this neighborhood.

Land use mix has been identified as a significant indicator to promote physical activity [67], which captures the number of potential destinations within a certain area. It is calculated as:

$$
\mathrm{H}=\sum_{\mathrm{i}=1}^{\mathrm{n}}\left(\frac{\mathrm{A}_{\mathrm{i}}}{\mathrm{A}_{\mathrm{c}}} \times \ln \frac{\mathrm{A}_{\mathrm{i}}}{\mathrm{A}_{\mathrm{c}}}\right)
$$

where $\mathrm{H}$ is the level of land use mix of each neighborhood; $n$ is the number of land use types, $A_{i}$ is the land area of the ith type, and $A_{c}$ is the total land area.

The second built environment element was road systems. Its measurement captured the level of air pollution generated from automobiles as one of the crucial risk factors for respiratory health. Dense road systems and short distances to heavy traffic roads increase the exposure to air pollutants. We employed road density and distance to the elevated highways and arterial roads as proxy variables. We adopted road systems instead of actual traffic volume to measure the level of air pollution generated from automobiles due to the limited data. Road systems could represent to a great extent the traffic level in our study because roads maintain consistent traffic volumes according to its capacity in this high-density urban district. Moreover, we used intersection density within a neighborhood, which may increase wind speed and thus decrease the concentration of air pollutants.

The third built environment element was spatial form. It attempted to capture the 3-Dimensional built environment variables and its impact, which were important and unique features for high density 
urban areas. The main criteria to select variables was the possible impact on wind speed and pollutants distribution. We used a total of five proxy variables to measure building density (floor area ratio, building coverage) and building form (building height, frontal area density, and building width-height ratio). Among them, floor area ratio (FAR) as a typical indicator to measure building mass was calculated by the total floor area of buildings within a parcel divided by its total land area. Building coverage was calculated by the first-floor area of buildings within a parcel divided by its total land area.

To capture the possible wind speed, the frontal area density was adopted as a proxy variable. It was calculated by the façade frontal area of a building to a certain wind direction divided by the total floor area of a neighborhood [68], as in the following formula:

$$
\lambda_{\mathrm{f}(\mathrm{z}, \theta)}=\frac{\mathrm{A}(\theta)_{\operatorname{proj}(\mathrm{z})}}{\mathrm{A}_{\mathrm{T}}},
$$

where $\mathrm{A}(\theta) \operatorname{proj}(\mathrm{z})$ is the façade frontal area of a building facing to a certain wind direction, $\theta$ is wind direction, AT is the total land area of a neighborhood, and $\mathrm{z}$ is the building height (see Figure A2).

The building width-height ratio also influences the wind speed and therefore the distribution of pollutants. It was calculated by the first-floor area of a building divided by its overall facade frontal area as in the following formula:

$$
\varepsilon=\sum_{\mathrm{i}=1}^{\mathrm{n}} \frac{\mathrm{A}_{\mathrm{i}}}{\mathrm{S}_{\mathrm{i}} * \mathrm{Z}}
$$

where $\varepsilon$ is the building width-height ratio, $\mathrm{n}$ is the number of buildings, Ai is the first-floor area of the $\mathrm{ith}$ building, $\mathrm{Si}$ is the perimeter of the ith building's façade, $\mathrm{z}$ is the building height, and $\mathrm{S}_{\mathrm{i}} * \mathrm{Z}$ represents the overall frontal area of the ith building.

Meanwhile, the demographic and economic status of a neighborhood were included as covariates because disparities may influence lifestyle, accessibility to health resources, and health outcomes. We included population density, gender, population with high education, occupation, and housing quality, which were measured by its corresponding proxy variables. Population density is the number of population divided by the area. Gender is the rate of females. Population with high education is the percentage of population with a bachelor's degree above the total population. Occupation is the percentage of population engaged in manufacturing. Housing quality is the percentage of families with living areas less than $30 \mathrm{~m}^{2}$.

\subsection{Modeling}

We firstly used Spearman's rank correlation to test the correlation between the mortality of COPD and the built environment variables. Then, we used a geographically weighted regression (GWR) model to unravel the impact of urban-built environments on the COPD mortality in high density areas. As an improvement on the traditional linear regression model and essentially a locally weighted least square method, the GWR model attempted to capture characteristics of specific spatial locations and its impact on the dependent variable.

The geographically weighted regression model is shown as follows:

$$
\mathrm{y}_{\mathrm{i}}=\beta_{0}\left(\mathrm{u}_{\mathrm{i}}, \mathrm{v}_{\mathrm{i}}\right)+\sum_{\mathrm{k}=1}^{\mathrm{p}} \beta_{\mathrm{k}}\left(\mathrm{u}_{\mathrm{i}}, \mathrm{v}_{\mathrm{i}}\right) \mathrm{x}_{\mathrm{ik}}+\varepsilon_{\mathrm{i}}(\mathrm{i}=1,2, \ldots, \mathrm{n}),
$$

where $\left(u_{i}, v_{i}\right)$ is the longitude and latitude coordinates of the ith sampling point, and $\beta_{k}\left(u_{i}, v_{i}\right)$ is the kth regression parameter at the ith sampling point.

We employed a stepwise regression process to identify significant variables. The explanatory variables were added to the GWR model step-by-step and the AICc of each model was compared so that the model with the lowest AICc was selected as the final model. Multicollinearity was measured by the variance inflation factor (VIF). No serious multicollinearity with a VIF $>10$ was indicated in the GWR model. The GWR model with a Gaussian kernel form and a fixed, CV-optimized bandwidth was performed in ESRI ArcGIS 10.2 (ESRI, Redlands, CA, USA). 


\section{Results}

\subsection{Spearman's Rank Correlation Analysis}

The results of the Spearman's rank correlation analysis were shown in Table 1. Land use mix was the only significant variable and showed negative correlation with COPD mortality in the land use category. As for road systems, both total road density and arterial road density were found to be positively correlated with COPD mortality. For spatial form, the frontal area density was negatively correlated with COPD mortality, while the building width-height ratio was positively correlated with COPD mortality. The population density had a negative correlation with COPD mortality, while other demographic and economic variables had no significant correlation with COPD mortality.

Table 1. Spearman's rank correlation test on the relationship between independent variables and COPD mortality.

\begin{tabular}{|c|c|c|c|c|}
\hline Categories & Sub-Categories & Variables & $\begin{array}{l}\text { Correlation } \\
\text { Coefficient }\end{array}$ & Sig. (Double Side) \\
\hline \multirow{3}{*}{ Land use } & Residential & Residential patch density & -0.118 & 0.331 \\
\hline & Open space & Open space patch density & -0.055 & 0.648 \\
\hline & Land use mix & Land use mix & $-0.247^{*}$ & 0.040 \\
\hline \multirow{5}{*}{ Road systems } & \multirow{2}{*}{ Road density } & Total road density & $0.482 * *$ & 0.000 \\
\hline & & Arterial road density & $0.535 * *$ & 0.000 \\
\hline & \multirow{2}{*}{ Distance to roads } & Shortest distance to the elevated highway & 0.025 & 0.838 \\
\hline & & Shortest distance to arterial road & 0.056 & 0.643 \\
\hline & Connectivity & Intersection density & -0.126 & 0.298 \\
\hline \multirow{5}{*}{ Spatial form } & \multirow{2}{*}{ Building density } & FAR (Floor area ratio) & -0.111 & 0.361 \\
\hline & & Building coverage & -0.073 & 0.547 \\
\hline & \multirow{3}{*}{ Building form } & Building height & -0.134 & 0.267 \\
\hline & & Frontal area density & $-0.460 * *$ & 0.000 \\
\hline & & Building width-height ratio & $0.408 * *$ & 0.000 \\
\hline \multirow{5}{*}{$\begin{array}{l}\text { Demographic and } \\
\text { economic status }\end{array}$} & Population density & Population density & $-0.540 * *$ & 0.000 \\
\hline & Gender & Female ratio & -0.121 & 0.317 \\
\hline & Education & High education rate & -0.143 & 0.237 \\
\hline & Occupation & Employment in the secondary industry & 0.122 & 0.315 \\
\hline & Housing quality & Housing area below $30 \mathrm{~m}^{2}$ & 0.034 & 0.777 \\
\hline
\end{tabular}

Note: ${ }^{*} p<0.05,{ }^{* *} p<0.01$.

\subsection{GWR}

The overall $\mathrm{R}^{2}$ and adjusted $\mathrm{R}^{2}$ of the model, which reflected the fitness of the geographical weighted regression, was 0.644 and 0.552 , respectively. The local $\mathrm{R}^{2}$ ranged from 0.32 to 0.64 from the west to the east of Jing'an District. This indicated that the local fitting degree of the model in the eastern neighborhoods was better than that in the western neighborhoods (Figure 3).

The results of the geographic weighted regression model illustrated that building width-height ratio was positively correlated with the mortality of COPD with the unstandardized coefficient changing with geographical location from 2792.48 to 7877.60 (Figure 4a). Moreover, the neighborhoods with high values of the local coefficient of building width-height ratio were located in the east of the district, which was matched to the spatial units with good model fittings. Frontal area density was also positively correlated to the mortality of COPD with the highest coefficient in the east of the district (Figure 4b). The unstandardized coefficient of frontal area density varied from 203.59 to 2057.25. In contrast, population density was negatively correlated to the mortality of COPD with the unstandardized coefficient from -6.57 to -0.13 (Figure $4 \mathrm{c}$ ). The spatial distribution of the population density coefficient was basically consistent to that of local $\mathrm{R}^{2}$, in which high-value neighborhoods were in the east while low-value ones were in the west. The building width-height ratio, frontal area density, and population density had a single direction of influence, though the magnitude of the coefficients varied geographically. 
The mortality of COPD was more sensitive to the changes in building width-height ratio, frontal area density, and population density in the east district than in the west district. However, the influencing direction of land use mix and arterial road density varied geographically. The coefficient of land use mix ranged from -845.31 to 109.57 , indicating that the association between land use mix and the mortality of COPD varied from a negative correlation to positive correlation (Figure 4d). Specifically, the land use mix was negatively correlated to the mortality of COPD in most neighborhoods except the northwest areas, in which the land use mix was positively correlated to the mortality of COPD. Arterial road density was also significantly correlated to the mortality of COPD with different directions. The coefficient of arterial road density ranged from -8.20 to 21.15 from east to west (Figure 4e). This indicated that the association between arterial road density and the mortality of COPD was negative in east neighborhoods and positive in west neighborhoods.

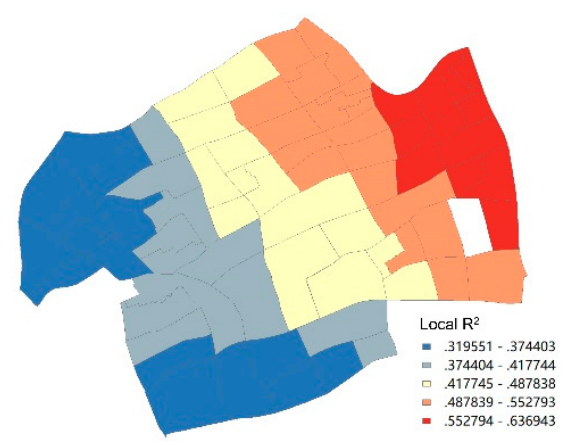

Figure 3. Local $\mathrm{R}^{2}$ Value distribution.

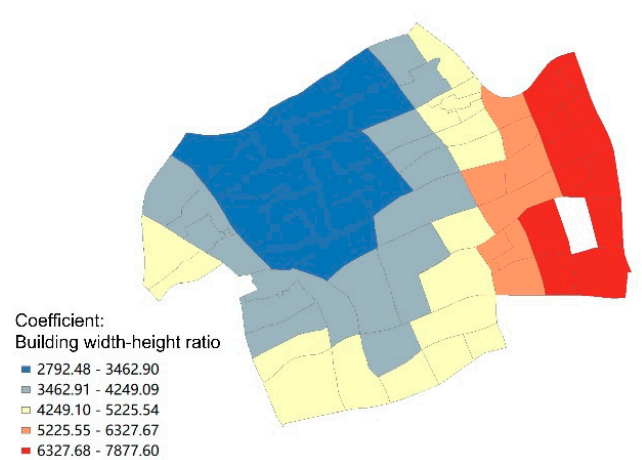

(a)

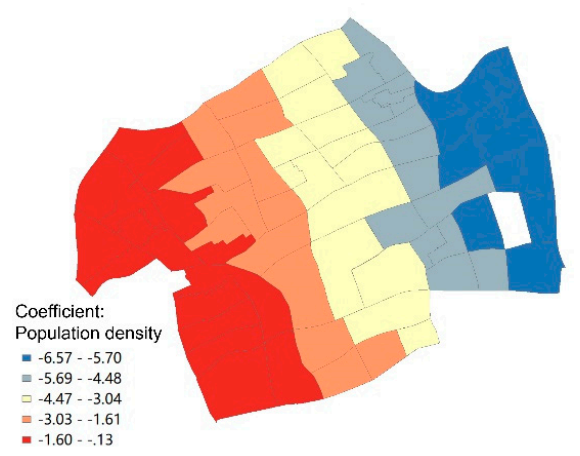

(c)

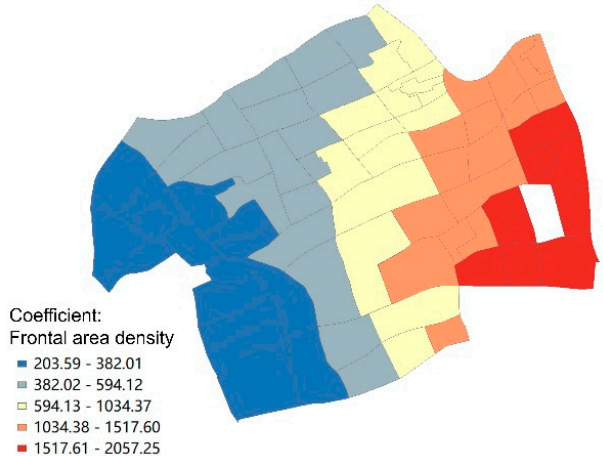

(b)

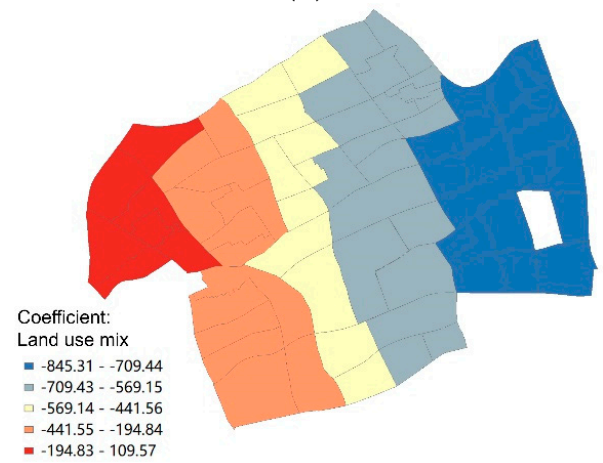

(d)

Figure 4. Cont. 


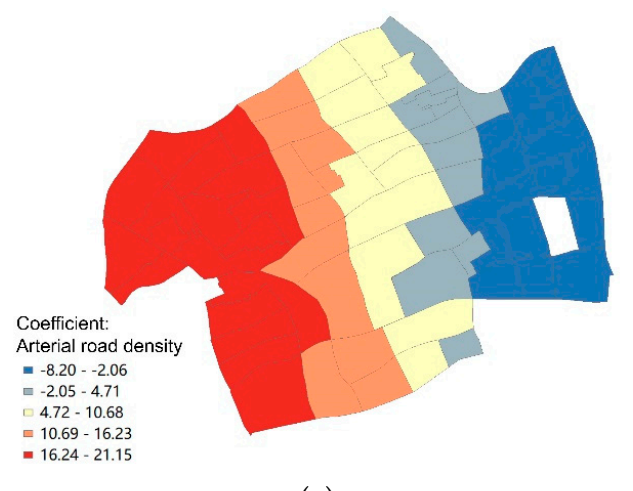

(e)

Figure 4. Spatial distribution of local coefficients of various significant influencing factors.

\section{Discussion}

Studies have noted that urban built environments have impacts on respiratory health by influencing air quality and human behavior such as physical activity [3]. The complexity of its impact, however, remains unraveled. We used COPD, one of the typical respiratory diseases, to explore its association to urban built environments. Geographical variation was also analyzed by developing a geographically weighted regression model, because built environmental elements may present different functions at different locations. With the strength of the GWR model, we identified significant built environmental elements and revealed geographical variation in terms of its magnitude and direction. Moreover, we selected proxy variables to measure modifiable features of urban built environments within a typical high-density district in Shanghai. By identifying built environmental elements adjustable by urban planning or public policy, we could improve respiratory health correspondingly.

As an important land use indicator, most prior findings proved a positive effect of land use mix, meaning that a higher level of mixture would promote respiratory health [22]. This was in line with this study when we found that the mortality of COPD was negatively correlated to the land use mix in most neighborhoods. Land use mix providing multiple destinations within walkable distance would reduce the usage of motor vehicles and then decrease carbon emission and air pollution $[69,70]$. Physical activities such as walking and cycling would be also promoted.

For road systems, we found arterial road density had a significant impact and geographical variation on the mortality of COPD. The magnitude of arterial road density's influence on COPD decreased from west to east. Moreover, the correlation between arterial road density and the COPD mortality was positive in neighborhoods in the west, while it was negative in the eastern area. Two possible effects of arterial road density may be verified, including generating air pollutants and providing accessibility to healthcare facilities. Prior findings supported that myocardial infarction, heart and respiratory failure and their acute attacks could increase the death risk among COPD patients $[9,10,12]$. Emergency aid mainly depends on the accessibility to hospitals in China. At present, Chinese cities were developing 15-min first-aid circles in order to shorten the first-aid time and reduce mortality. For these reasons, the efficiency of ambulances has a great relationship with the traffic time and distance from the patient's residence to the hospital. Due to the consistent heavy traffic on the road, the distance of medical facilities is particularly important in the high-density central city. In the western area with more hospitals, the effect of accessing healthcare facilities played a more significant role than that of generating air pollutants. On the contrary, air pollution caused by traffic on arterial roads outweighed the effect of healthcare facilities accessibility in the eastern neighborhoods. This finding contributed to the existing literature by revealing multiple effects of arterial roads, which could affect respiratory health in different ways in specific areas. The allocation of healthcare facilities such as hospitals need to consider road systems to support its emergency treatment.

Among the variables of spatial form, we identified building form with proxy variables of frontal area density and building width-height ratio as significant variables instead of building 
density. Although the magnitude of correlation varied geographically, the direction of the effects was positive. Both of these two proxy variables measured the effect of building layout on the wind situation. The frontal area density was defined as the ratio of floor area to windward area of buildings. Low frontal area density was conducive for ventilation. It could accelerate the diffusion of particulate matter and then reduce its concentration [40,41]. Building width-height ratio measured the shape of buildings and its impact on wind speed. The higher the building width-height ratio, the slower the wind speed and the higher the concentration of air pollutants. It was also notable that the high-degree of correlation was located in the east of the district, which was also the low-density area for both building width-height ratio and frontal area density. This indicates that the mortality of COPD is likely to be more sensitive to the building form in low density areas.

For demographic and economic status, we found that population density was negatively correlated to the mortality of COPD, which was inconsistent to most prior studies [61]. Previous studies that found a positive correlation between population density and mortality were often concluded by comparing the differences between urban and rural areas. It may be different because we examined the population density in the extremely high urbanized areas. The potential explanation for this result may be that the area of high population density in Jing'an District was associated with high-rise residential building developed after 1990s with better housing quality. The area of low population density was occupied with linong and workers' new village with relevant poor housing quality and infrastructure.

The findings of the GWR model identified not only the significant variables but also its geographical variation. It provided opportunity to explore multiple effects of built environment within a specific context. The association between the respiratory health and land use mix, arterial road density, building form and demographic features identified in this study led to the rethinking of principles of urban planning and policy making.

The first limitation of this study is the lack of key information about smoking and genetics, which may affect the analysis results. The second limitation is that we are unable to capture the dynamic changes of the environment with the times, so that the variation in the temporal effects of the built environment on respiratory health is ignored in this study. The third limitation is that the built environment mainly refers to living places in this study and the built environment of the residents' workplace is not well considered. The impact of the built environment on respiratory health may be overestimated.

\section{Conclusions}

This study contributes to a better understanding of the complex relationship between urban built environments and respiratory health. Land use mix, arterial road density, building form, and demographic features have geographically varied effects on COPD.

The findings can provide an empirical basis for environmental intervention in high-density areas. The mixed pattern of land use can be encouraged to promote physical activities such as walking and cycling and improve residents' respiratory health. Both positive and negative effects of road network density should be considered in urban planning. The allocation of healthcare facilities such as hospitals need to consider road systems to support emergency treatment. For building form, we shall reduce its frontal area to increase wind speed for better distribution of air pollutants. With the same floor area, the narrow façade might be preferred for respiratory health. Building form affects the circulation of wind, especially in high-density areas. Special attention should be paid to the impact of new construction and urban development on the wind environment.

Future studies shall include data about other risk factors such as smoking, genetics, and work exposure. The changes in built environment and real-time traffic volume to capture air pollution generated from automobiles should also be considered. Moreover, this study implied that the proximity to hospitals might be a possible reductive factor for COPD mortality. It is necessary to consider the accessibility to hospitals and parks within and outside the study area. Further research remains necessary on the accurate estimation of emergency time in different built environments. 
Author Contributions: Conceptualization, L.W., X.Y. and X.L.; Methodology, L.W. and X.L.; Formal analysis, L.W., R.C. and W.S.; Investigation, R.C.; Resources, X.Y.; Writing-Original draft preparation, all authors; Writing-Review \& editing, all authors. All authors have read and agreed to the published version of the manuscript.

Funding: This research was funded by "NNSFC, 41871359, 51578384, 41671444" and "Beijing Advanced Innovation Center for Future Urban Design, Beijing University of City Engineering and Architecture, udc2018010921".

Conflicts of Interest: The authors declare no conflict of interest.

\section{Appendix A}

Table A1. Measurement and impact of the built environment: demographic and economic factors.

\begin{tabular}{|c|c|c|c|c|c|}
\hline Categories & Sub-Categories & Variables & Unit & Definition & $\begin{array}{l}\text { Potential Impact in } \\
\text { Hypotheses }\end{array}$ \\
\hline \multirow{3}{*}{ Land use } & Residential & $\begin{array}{l}\text { Residential } \\
\text { patch density }\end{array}$ & piece $/ \mathrm{hm}^{2}$ & $\begin{array}{c}\text { Number of residential } \\
\text { land/neighborhood total } \\
\text { land area }\end{array}$ & $\begin{array}{l}\text { Higher density increases } \\
\text { human exposure to } \\
\text { air pollutants }\end{array}$ \\
\hline & Open space & $\begin{array}{l}\text { Open space } \\
\text { patch density }\end{array}$ & piece $/ \mathrm{hm}^{2}$ & $\begin{array}{c}\text { Number of open space } \\
\text { land/neighborhood total } \\
\text { land area }\end{array}$ & $\begin{array}{l}\text { Higher density increases } \\
\text { human exposure to } \\
\text { air pollutants }\end{array}$ \\
\hline & Land use mix & Land use mix & / & $H=\sum_{i=1}^{n}\left(\frac{A_{i}}{A_{c}} * \ln \frac{A_{i}}{A_{c}}\right)$ & $\begin{array}{l}\text { Decrease the usage of } \\
\text { automobile and thus reduce } \\
\text { air pollution }\end{array}$ \\
\hline \multirow{5}{*}{ Road system } & \multirow{2}{*}{ Road density } & $\begin{array}{c}\text { Total road } \\
\text { density }\end{array}$ & $\mathrm{km} / \mathrm{km}^{2}$ & $\begin{array}{l}\text { Road length/neighborhood } \\
\text { total land area }\end{array}$ & $\begin{array}{l}\text { Increase traffic volume and } \\
\text { its air pollution }\end{array}$ \\
\hline & & $\begin{array}{l}\text { Arterial road } \\
\text { density }\end{array}$ & $\mathrm{km} / \mathrm{km}^{2}$ & $\begin{array}{c}\text { Arterial road } \\
\text { length/neighborhood total } \\
\text { land area } \times 1000\end{array}$ & $\begin{array}{l}\text { Increase traffic volume and } \\
\text { its air pollution }\end{array}$ \\
\hline & \multirow[t]{2}{*}{$\begin{array}{l}\text { Distance to } \\
\text { roads }\end{array}$} & $\begin{array}{l}\text { Shortest } \\
\text { distance to the } \\
\text { elevated } \\
\text { highway }\end{array}$ & $\mathrm{m}$ & $\begin{array}{l}\text { Shortest distance to the } \\
\text { elevated highway }\end{array}$ & $\begin{array}{c}\text { The shorter distance implies } \\
\text { more human exposure to } \\
\text { air pollution }\end{array}$ \\
\hline & & $\begin{array}{c}\text { Shortest } \\
\text { distance to } \\
\text { arterial road }\end{array}$ & $\mathrm{m}$ & $\begin{array}{l}\text { Shortest distance to } \\
\text { arterial road }\end{array}$ & $\begin{array}{l}\text { The shorter distance implies } \\
\text { more human exposure to } \\
\text { air pollution }\end{array}$ \\
\hline & Connectivity & $\begin{array}{l}\text { Intersection } \\
\text { density }\end{array}$ & quantity $/ \mathrm{hm}^{2}$ & $\begin{array}{c}\text { Intersections } \\
\text { number/neighborhood } \\
\text { total land area }\end{array}$ & $\begin{array}{l}\text { Increase wind speed and } \\
\text { thus decrease the } \\
\text { concentration of } \\
\text { air pollutants. }\end{array}$ \\
\hline \multirow{5}{*}{ Spatial form } & \multirow{2}{*}{$\begin{array}{l}\text { Building } \\
\text { density }\end{array}$} & $\begin{array}{c}\text { FAR } \\
\text { (Floor area ratio) }\end{array}$ & / & $\begin{array}{l}\text { Above-ground building } \\
\text { Area/parcel land area }\end{array}$ & $\begin{array}{l}\text { High density increase the } \\
\text { concentration of } \\
\text { air pollutants }\end{array}$ \\
\hline & & $\begin{array}{l}\text { Building } \\
\text { coverage }\end{array}$ & $\%$ & $\begin{array}{c}\text { Building area/parcel land } \\
\text { area }\end{array}$ & $\begin{array}{l}\text { High density increase the } \\
\text { concentration of } \\
\text { air pollutants }\end{array}$ \\
\hline & \multirow{3}{*}{ Building form } & Building height & l & $\begin{array}{l}\text { Standard deviation of } \\
\text { building height }\end{array}$ & $\begin{array}{l}\text { High density increase the } \\
\text { concentration of } \\
\text { air pollutants }\end{array}$ \\
\hline & & $\begin{array}{l}\text { Frontal area } \\
\text { density }\end{array}$ & l & $\begin{array}{c}\sum \text { (Frontal area of a } \\
\text { building facing to a certain } \\
\text { wind direction)/parcel } \\
\text { land area }\end{array}$ & $\begin{array}{l}\text { High density decrease wind } \\
\text { speed and thus increase the } \\
\text { concentration of } \\
\text { air pollutants }\end{array}$ \\
\hline & & $\begin{array}{l}\text { Building } \\
\text { width-height } \\
\text { ratio }\end{array}$ & l & Building area/frontal Area & $\begin{array}{l}\text { High density decrease wind } \\
\text { speed and thus increase the } \\
\text { concentration of } \\
\text { air pollutants }\end{array}$ \\
\hline \multirow{5}{*}{$\begin{array}{l}\text { Demographic } \\
\text { and economic } \\
\text { status }\end{array}$} & $\begin{array}{l}\text { Population } \\
\text { density }\end{array}$ & $\begin{array}{l}\text { Population } \\
\text { density }\end{array}$ & persons $/ \mathrm{hm}^{2}$ & $\begin{array}{c}\text { Total } \\
\text { population/neighborhood } \\
\text { total land area }\end{array}$ & $\begin{array}{l}\text { Affect the morbidity } \\
\text { and mortality }\end{array}$ \\
\hline & Gender & Female ratio & $\%$ & Women/total population & $\begin{array}{l}\text { Affect the morbidity } \\
\text { and mortality }\end{array}$ \\
\hline & Education & $\begin{array}{l}\text { High education } \\
\text { rate }\end{array}$ & $\%$ & $\begin{array}{l}\text { Bachelor degree or } \\
\text { above/total }\end{array}$ & $\begin{array}{l}\text { Life style and knowledge } \\
\text { affect the morbidity } \\
\text { and mortality }\end{array}$ \\
\hline & Occupation & $\begin{array}{l}\text { Employment in } \\
\text { the secondary } \\
\text { industry }\end{array}$ & $\%$ & $\begin{array}{c}\text { Production, transportation } \\
\text { equipment operators/total } \\
\text { employment }\end{array}$ & $\begin{array}{l}\text { Work exposure increases the } \\
\text { mortality and mortality }\end{array}$ \\
\hline & $\begin{array}{l}\text { Housing } \\
\text { quality }\end{array}$ & $\begin{array}{l}\text { Housing area } \\
\text { below } 30 \mathrm{~m}^{2}\end{array}$ & $\%$ & $\begin{array}{l}\text { Average per unit living } \\
\text { area less than } 30 \mathrm{~m}^{2}\end{array}$ & $\begin{array}{l}\text { Low housing quality } \\
\text { increases the mortality } \\
\text { and mortality }\end{array}$ \\
\hline
\end{tabular}



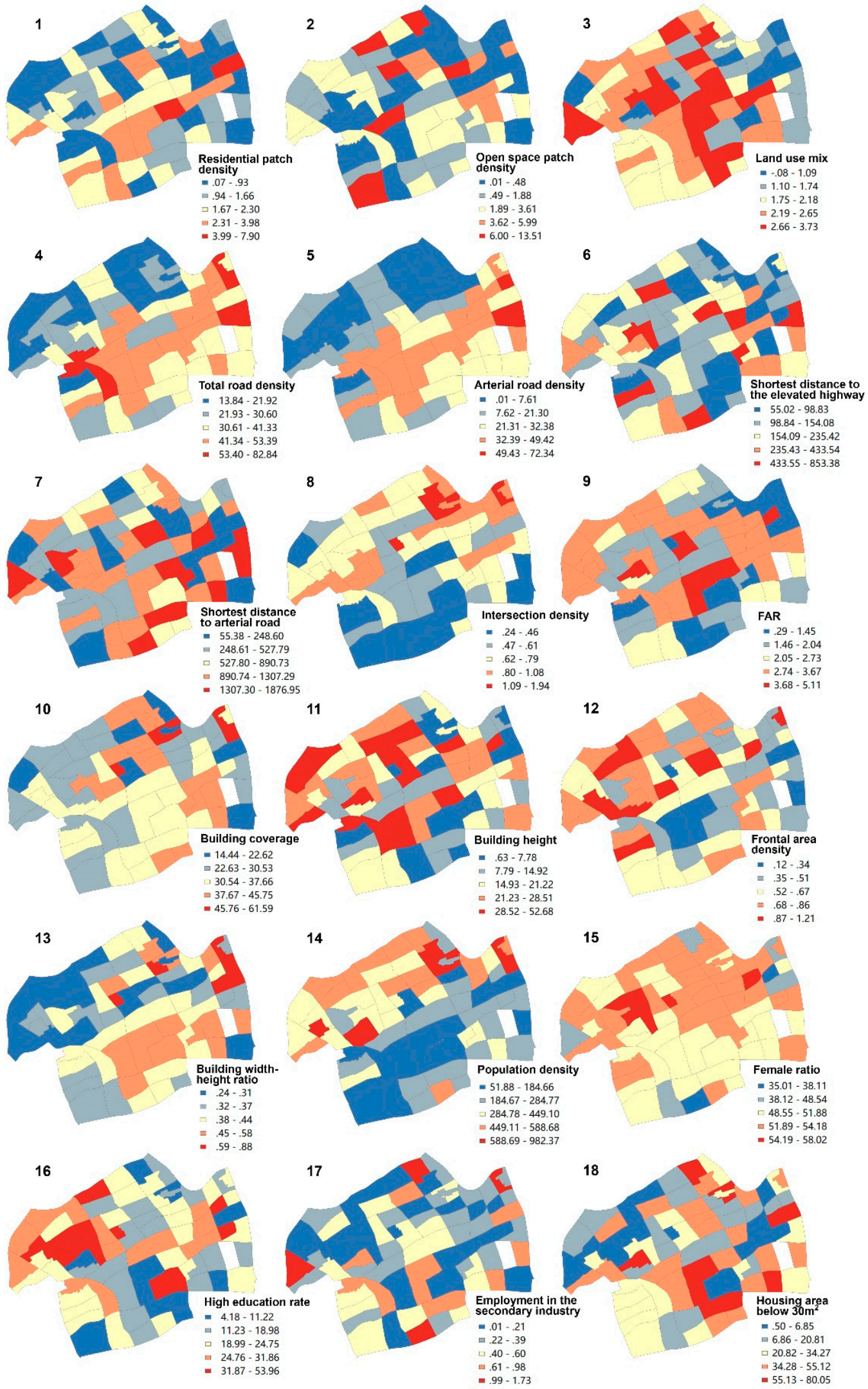

Figure A1. Spatial distribution of built environment elements. 

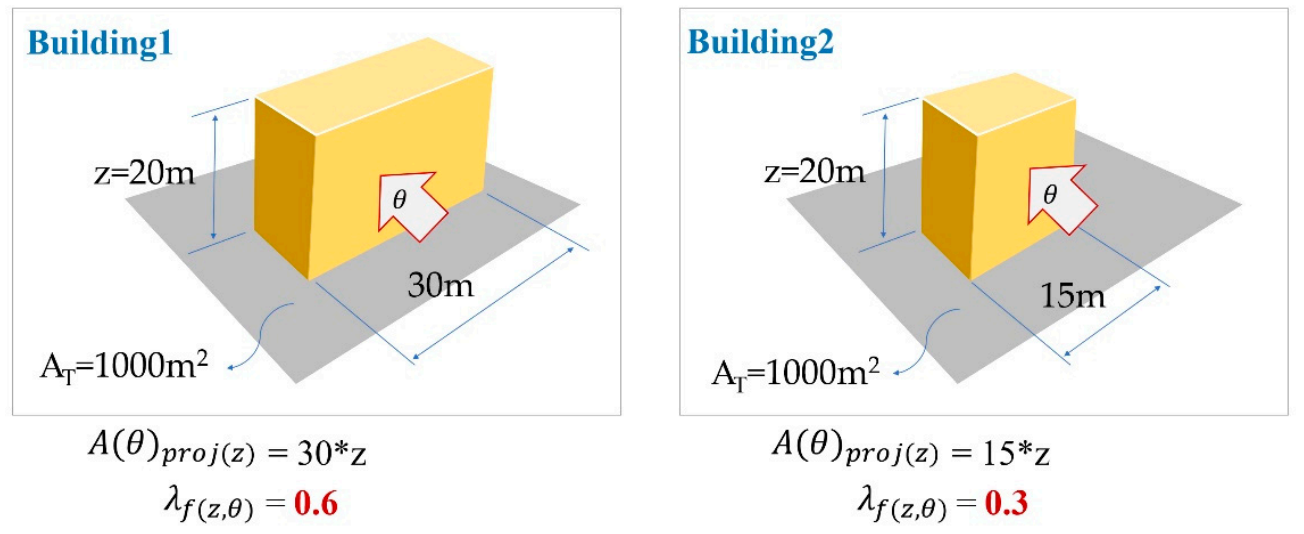

Figure A2. Measurement of frontal area density.

\section{References}

1. The Top 10 Causes of Death. Available online: https://www.who.int/news-room/fact-sheets/detail/the-top10-causes-of-death (accessed on 8 December 2019).

2. Transcript of Press Conference on 31 July 2019. Available online: http://www.nhc.gov.cn/xcs/s7847/201907/ 0d95adec49f84810a6d45a0a1e997d67.shtml (accessed on 8 December 2019).

3. Global Initiative for Chronic Obstructive Lung Disease, Inc. Global Strategy for the Diagnosis, Management, and Prevention of Chronic Obstructive Pulmonary Disease 2019 Report; Global Initiative for Chronic Obstructive Lung Disease, Inc.: Fontana, WI, USA, 2019.

4. Chronic Obstructive Pulmonary Disease (COPD). Available online: https://www.who.int/news-room/factsheets/detail/chronic-obstructive-pulmonary-disease-(COPD) (accessed on 8 December 2019).

5. Bentayeb, M.; Simoni, M.; Baiz, N.; Norback, D.; Baldacci, S.; Maio, S.; Viegi, G.; Annesimaesano, I. Adverse respiratory effects of outdoor air pollution in the elderly. Int. J. Tuberc. Lung Dis. 2012, 16, 1149-1161. [CrossRef]

6. Qian, Y.; Han, M.; Jin, W.; Cai, R.; Fang, B.; Yu, H.; Qian, N.; Wang, C. Association between ambient air pollution and COPD mortality in Shanghai. J. Environ. Occup. Med. 2015, 32, 1093-1097.

7. Ju, J.; Ge, M.; Jia, Q.; Yang, H. Relationship between the mortality of chronic obstructive pulmonary disease and the air pollution in Suzhou. J. Clin. Pulm. Med. 2012, 17, 2136-2138.

8. Van den Berg, M.E.; Stricker, B.H.; Brusselle, G.G.; Lahousse, L. Chronic obstructive pulmonary disease and sudden cardiac death: A systematic review. Trends Cardiovasc. Med. 2016, 26, 606-613. [CrossRef] [PubMed]

9. Yao, L. Common causes of chronic obstructive pulmonary disease and risk factors for death. Med. Equip. 2019, 32, 108-109.

10. Rothnie, K.J.; Yan, R.; Smeeth, L.; Quint, J.K. Risk of myocardial infarction (MI) and death following MI in people with chronic obstructive pulmonary disease (COPD): A systematic review and meta-analysis. BMJ Open 2015, 5, e007824. [CrossRef] [PubMed]

11. Putcha, N.; Drummond, M.B.; Connett, J.E.; Scanlon, P.D.; Tashkin, D.P.; Hansel, N.N.; Wise, R.A. Chronic productive cough is associated with death in smokers with early COPD. J. Chronic Obstr. Pulm. Dis. 2014, 11, 451-458. [CrossRef] [PubMed]

12. Zhang, D.; Zou, X.; Xin, D.; Deng, Q. Risk factors of death in 88 cases with chronic obstructive pulmonary disease. Guangdong Med. 2007, 961-963. [CrossRef]

13. Schamberger, A.C.; Mise, N.; Meiners, S.; Eickelberg, O. Epigenetic mechanisms in COPD: Implications for pathogenesis and drug discovery. Expert Opin. Drug Discov. 2014, 9, 609-628. [CrossRef]

14. Xu, F.; Liang, Y.; Shen, H.; Xu, Y. Years of potential life 10st of chronic obstructive pulmonary diseases among residents in Nanjing from 1997 to 2005. Chin. J. Epidemiol. 2007, 18, 203-204.

15. Sai, X.; He, Y.; Wang, B.; Meng, D.; Xing, Q.; Xiao, D.; Wang, Y.; Yan, Y. An 18-year follow up study on the risk factors of deaths regarding chronic obstructive pulmonary disease in $\mathrm{Xi}$ 'an, China. Chin. J. Epidemiol. 2006, 27, 765-768.

16. Pope, C.A.; Bates, D.V.; Raizenne, M.E. Health effects of particulate air pollution: Time for reassessment? Environ. Health Perspect. 1995, 103, 472-480. [CrossRef] [PubMed] 
17. Dockery, D.W.; Pope, C.A.; Xu, X.; Spengler, J.D.; Ware, J.H.; Fay, M.E.; Ferris, B.G.; Speizer, F.E. An association between air pollution and mortality in six U.S. Cities. N. Engl. J. Med. 1993, 329, 1753. [CrossRef] [PubMed]

18. Perdue, W.C.; Stone, L.A.; Gostin, L.O. The built environment and its relationship to the public's health: The legal framework. Am. J. Public Health 2003, 93, 1390-1394. [CrossRef] [PubMed]

19. Blanco, I.; Diego, I.; Bueno, P.; Fernández, E.; Casas-Maldonado, F.; Esquinas, C.; Soriano, J.B.; Miravitlles, M. Geographical distribution of COPD prevalence in the Americas. COPD 2018, 15, 317-325. [CrossRef]

20. Raju, S.; Keet, C.A.; Paulin, L.M.; Matsui, E.C.; Peng, R.D.; Hansel, N.N.; McCormack, M.C. Rural residence and poverty are independent risk factors for COPD in the United States. Am. J. Respir. Crit. Care Med. 2019, 199, 961-969. [CrossRef]

21. Halvorsen, T.; Martinussen, P.E. The geography of chronic obstructive pulmonary disease: A population-based study of Norway. Soc. Sci. Med. 2014, 111, 25-34. [CrossRef]

22. Wang, L.; Liao, S.; Zhao, X. Exploration of approaches and factors of healthy city planning. Urban Plan. Int. 2016, 31, 4-9. [CrossRef]

23. Zou, B.; $\mathrm{Xu}, \mathrm{S}$.; Zhang, J. Spactial variation analysis of urban air pollution using gis: A land use perspective. Geomat. Inf. Sci. Wuhan Univ. 2017, 42, 216-222.

24. Ko, F.W.; Hui, D.S. Air pollution and chronic obstructive pulmonary disease. Respirology 2012, 17, $395-401$. [CrossRef]

25. Maurizio, M.; Claudio, N.; Matteo, V.; Carmela, P.; Pasquale, A. Pedestrians in traffic environments: Ultrafine particle respiratory doses. Public Health 2017, 14, 288.

26. Aziz, A.; Bajwa, I.U. Minimizing human health effects of urban air pollution through quantification and control of motor vehicular carbon monoxide (co) in Lahore. Environ. Monit. Assess. 2007, 135, 459-464. [CrossRef] [PubMed]

27. Schikowski, T.; Sugiri, D.; Ranft, U.; Gehring, U.; Heinrich, J.; Wichmann, H.; Krämer, U. Long-term air pollution exposure and living close to busy roads are associated with COPD in women. Respir. Res. 2005, 6, 1-10. [CrossRef] [PubMed]

28. Tiwary, A.; Robins, A.; Namdeo, A.; Bell, M. Air flow and concentration fields at urban road intersections for improved understanding of personal exposure. Environ. Int. 2011, 37, 1005-1018. [CrossRef] [PubMed]

29. Qiu, Q.; Wang, L. To research for street geometry structure planning based on polluting mechanism in street canyon. Urban Stud. 2007, 14, 78-82.

30. Aliya, B.; Zhen, J.; Sun, Q.; Kahaer, Z. Pollution characteristics of $\mathrm{PM}_{2.5}$ and $\mathrm{PM}_{10}$ in forest belts along expressway in Urumqi. Environ. Sci. Technol. 2019, 42, 103-108.

31. Ma, H.; Tan, H.; Hu, T. Research of vertical distribution characteristics of $\mathrm{PM}_{2.5}$ surrounding a roadside building. Build. Energy Environ. 2016, 35, 27-31.

32. Zhao, X.; Fan, Y.; Si, P.; Zhao, S.; Gou, Z. Pollution characteristics of indoor and outdoor particulate of buildings. J. Environ. Eng. Technol. 2016, 6, 223-228.

33. Li, S.; Shi, T.; Zhou, S.; Gong, J.; Zhu, L.; Zhou, Y. Diffusion effects of atmospheric pollutants on the three dimensional landscape pattern of urban block. J. Shenyang Jianzhu Univ. (Nat. Sci.) 2016, 32, 1111-1121.

34. Sun, S.; Gu, R.; Zhang, J. Inhalable particulate matter $\left(\mathrm{PM}_{10}\right)$ related to different green cover percentage and greenbelt types in Beijing. Chin. Landsc. Archit. 2004, 77-79. [CrossRef]

35. Zhao, Z.; Wang, Z.; Zhang, Y.; Zhang, S.; Wang, Y. Monitoring and analysis on the distribution of suspended particles near ground level in urban by plants leaves. Ecol. Environ. 2008, 17, 980-984.

36. Lou, C.; Liu, H.; Li, Y.; Li, Y. Research on the response of air particles $\left(\mathrm{PM}_{2.5}, \mathrm{PM}_{10}\right)$ to landscape structure: A review. Acta Ecol. Sin. 2016, 36, 6719-6729.

37. Li, S.; Zhu, L.; Shi, T.; Wang, W. The counter measures of urban street planning based on the pollution prevention of inhalant particle. Urban Dev. Stud. 2014, 42-45. [CrossRef]

38. Chan, A.T.; Au, W.T.W.; So, E.S.P. Strategic guidelines for street canyon geometry to achieve sustainable street air quality-Part II: Multiple canopies and canyons. Atmos. Environ. 2003, 37, 2761-2772. [CrossRef]

39. Depaul, F.T. A study of pollutant dispersion in an urban street canyon. Atmos. Environ. 1984, 19, 555-559. [CrossRef]

40. Yin, J.; Zhan, Q. The relationship between ventilation and urban morphology based on the method of morphology-Taking Wuhan as an example. Environ. Prot. 2016, 44, 59-63.

41. Shen, J.; Qiu, X.; He, Y.; Zeng, Y.; Li, M. Study on comparison of vector/raster calculation model of frontal area density of urban buildings. J. Geogr. Info. Sci. 2017, 19, 1433-1441. 
42. Rabe, K.F.; Watz, H. Chronic obstructive pulmonary disease. Lancet 2017, 389, 1931-1940. [CrossRef]

43. Spruit, M.; Pitta, F.; Mcauley, E.; Zuwallack, R.; Nici, L. Pulmonary rehabilitation and physical activity in patients with chronic obstructive pulmonary disease. Am. J. Respir. Crit. Care Med. 2015, 192, 924-933. [CrossRef]

44. Beeh, K.M.; Watz, H.; Puente-Maestu, L.; de Teresa, L.; Jarreta, D.; Caracta, C.; Garcia Gil, E.; Magnussen, H. Aclidinium improves exercise endurance, dyspnea, lung hyperinflation, and physical activity in patients with COPD: A randomized, placebo-controlled, crossover trial. BMC Pulm. Med. 2014, 14, 209. [CrossRef]

45. Watz, H.; Mailänder, C.; Baier, M.; Kirsten, A. Effects of indacaterol/glycopyrronium (qva149) on lung hyperinflation and physical activity in patients with moderate to severe COPD: A randomised, placebo-controlled, crossover study (the move study). BMC Pulm. Med. 2016, 16, 95. [CrossRef] [PubMed]

46. Watz, H.; Krippner, F.; Kirsten, A.; Magnussen, H.; Vogelmeier, C. Indacaterol improves lung hyperinflation and physical activity in patients with moderate chronic obstructive pulmonary disease-A randomized, multicenter, double-blind, placebo-controlled study. BMC Pulm. Med. 2014, 14, 158. [CrossRef] [PubMed]

47. Wai, J.; Yuan, T.; Cheng, D. Minimum amount of physical activity for reduced mortality and extended life expectancy: A prospective cohort study minimum amount of physical activity for reduced mortality and extended life expectancy: A prospective cohort study. Lancet 2016, 378, 1244-1253.

48. Demeyer, H.; Burtin, C.; Hornikx, M.; Camillo, C.A.; Van, R.H.; Langer, D.; Janssens, W.; Troosters, T. The minimal important difference in physical activity in patients with COPD. PLoS ONE 2016, 11, e0154587. [CrossRef] [PubMed]

49. De Souto Araujo, Z.T.; de Miranda Silva Nogueira, P.A.; Cabral, E.E.; de Paula Dos Santos, L.; da Silva, I.S.; Ferreira, G.M. Effectiveness of low-intensity aquatic exercise on COPD: A randomized clinical trial. Respir. Med. 2012, 106, 1535-1543. [CrossRef] [PubMed]

50. Belfer, M.H. The impact of exercise on activities of daily living and quality of life: A primary care physician's perspective. J. Chronic Obstr. Pulm. Dis. 2007, 4, 289-291. [CrossRef] [PubMed]

51. Guo, L.; Yang, W.; Bi, Y. Analysis of the impact of the built environment on the travel characteristics of residents-A case study of 8 blocks in Wuhan city. In Proceedings of the Annual Urban Traffic Planning Conference, Shenzhen, China, 15-16 April 2016.

52. Yang, D.; Liu, Z. The influence of built environment on senior activities: Daily shopping activity analysis. Planners 2015, 31, 101-105.

53. Tamura, K.; Puett, R.C.; Hart, J.E.; Starnes, H.A.; Laden, F.; Troped, P.J. Spatial clustering of physical activity and obesity in relation to built environment factors among older women in three U.S. States. BMC Public Health 2014, 14, 1322. [CrossRef]

54. Ana, M.; Vania, C.; Sara, V.; Carlos, S. Assessing and monitoring urban resilience using COPD in Porto. Sci. Total Environ. 2012, 414, 113-119.

55. Moreno, A.; Espinoza-Navarro, O. Copd in non-smoking elderly men at sea level and high altitude: Comparing anthropometric characteristics and physiological responses. Int. J. Morphol. 2013, 31, 618-622. [CrossRef]

56. Fu, G.; Zhang, X.; Liu, H. Study on the correlation between temperature and chronic obstructive pulmonary disease in Shijiazhuang, China-Retrospective cohort. J. Geosci. Environ. Prot. 2017, 5, 23-31. [CrossRef]

57. Aschan-Leygonie, C.; Baudet-Michel, S.; Mathian, H.; Sanders, L. Respiratory health inequalities between cities: A geographical approach. Environ. Risques Santé 2013, 12, 118-128.

58. Shanghai Statistical Yearbook. Available online: http://jj.sh.gov.cn/html/sjfb/201701/1000198.html (accessed on 8 December 2019).

59. Liu, W.X.; Gao, Z.; Muhetaer, A.; Halmurat, U. Analysis on risk factors of chronic obstructive pulmonary disease based on epidemiological survey in different areas of China. Med. Recapitul. 2013, 19, 1243-1246.

60. Cho, K.H.; Nam, C.M.; Lee, E.J.; Choi, Y.; Yoo, K.B.; Lee, S.H.; Park, E.C. Effects of individual and neighborhood socioeconomic status on the risk of all-cause mortality in chronic obstructive pulmonary disease: A nationwide population-based cohort study, 2002-2013. Respir. Med. 2016, 114, 9-17. [CrossRef]

61. Zhang, Q.; Huang, C.; Gong, Z.; Jia, G. Analysis of correlation relationship of population, economy, energy consumption and atmospheric environmental pollution in Berjing-Tianjin-Hebei region. Guangzhou Chem. Ind. 2017, 45, 138-140.

62. Yan, W. Sociological perspectives on air pollution: A cross-national analysis of social determinants of fine particulate matter $\left(\mathrm{PM}_{2.5}\right)$. Sociol. Rev. China 2015, 3, 53-67. 
63. Chen, J.; Schooling, C.M.; Johnston, J.M.; Hedley, A.J.; McGhee, S.M. How does socioeconomic development affect COPD mortality? An age-period-cohort analysis from a recently transitioned population in China. PLoS ONE 2011, 6, e24348. [CrossRef]

64. Byrne, A.L.; Marais, B.J.; Mitnick, C.D.; Lecca, L.; Marks, G.B. Risk factors for and origins of COPD. Lancet 2015, 1723-1724. [CrossRef]

65. Wang, C.; Xu, J.; Yang, L.; Xu, Y.; Zhang, X.; Bai, C.; Kang, J.; Ran, P.; Shen, H.; Wen, F.; et al. Prevalence and risk factors of chronic obstructive pulmonary disease in China (the China pulmonary health [cph] study): A national cross-sectional study. Lancet 2018, 391, 1706-1717. [CrossRef]

66. Liao, X.; Peng, D.; Wang, W.; Lei, Y.; Luo, F.; Yang, Z.; Su, Q.; Zou, C. Prevalence of COPD and its influential factors in rural urban community, Chengdu. Mod. Prev. Med. 2015, 42, 1543-1546.

67. Mccormack, G.R.; Shiell, A. In search of causality: A systematic review of the relationship between the built environment and physical activity among adults. Int. J. Behav. Nutr. Phys. Act. 2011, 8, 125. [CrossRef] [PubMed]

68. Burian, S.J.; Velugubantla, S.P.; Brown, M.J. Morphological analyses using 3d building databases: Salt Lake City, Utah. Analyst 2002, 4, 55-56.

69. Liu, C.; Shen, Q. An empirical analysis of the influence of urban form on household travel and energy consumption. Comput. Environ. Urban Syst. 2011, 35, 347-357. [CrossRef]

70. Hong, J.; Shen, Q. Residential density and transportation emissions: Examining the connection by addressing spatial autocorrelation and self-selection. Transp. Res. Part D 2013, 22, 75-79. [CrossRef]

(C) 2019 by the authors. Licensee MDPI, Basel, Switzerland. This article is an open access article distributed under the terms and conditions of the Creative Commons Attribution (CC BY) license (http://creativecommons.org/licenses/by/4.0/). 